\title{
ENTREVISTA
}

\section{[ANDRÉA KOGAN]}

Andréa Kogan é doutora em Ciência da Religião pela PUC-SP, onde defendeu sua tese sobre judaísmo e espiritismo, e mestre em turismo pela Unibero, onde estudou turismo religioso. É integrante do grupo de pesquisa NEMES (Núcleo de Estudos em Mística e Santidade, da PUC-SP) no qual estuda filosofia do judaísmo e judaísmo contemporâneo. Também organiza encontros e os seminários semestrais do grupo.

Nesta entrevista coloca-se o pensamento judaico e seus respectivos pensadores como atores centrais não apenas na tradição filosófica que influencia todo o pensamento posterior, mas também no nosso cenário religioso tão sincrético, além de apontar algumas características que o particularizam. O grupo NEMES aborda a religiosidade por um viés predominanentemente filosófico, procurando entender os fundamentos da crença nesta dimensão; após um longo período concentrando sua pesquisa em mística, o NEMES tem se dedicado, nos últimos anos, ao tema do judaísmo.

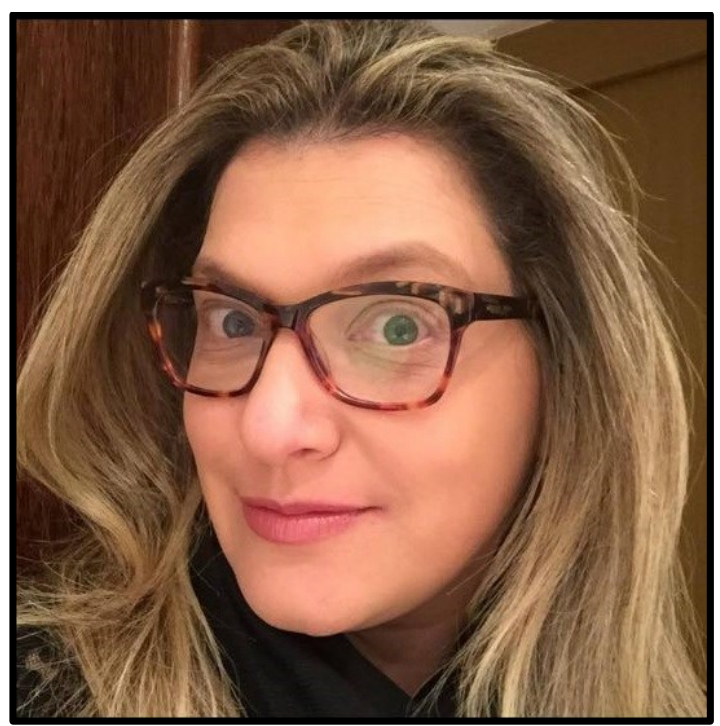


Último Andar: Muitas vezes chamamos de filosofia judaica aquela que é simplesmente feita por judeus - mas você acredita na existência de um "pensamento judaico" realmente? Ou de "pensadores judeus"? Ou seja, uma forma de pensamento essencialmente moldada pelo judaísmo?

Andréa Kogan: Acredito na existência de um "pensamento judaico" realmente e, é claro, de "pensadores judeus". Contudo, acho que a filosofia judaica moderna ultrapassa este limite. Utilizo aqui um trecho da introdução do livro The Cambridge Companion to Modern Jewish Philosophy de Michael L. Morgan e Peter Eli Gordon (livre tradução minha): "A filosofia judaica moderna foi e continua a ser o resultado de uma relação multifacetada entre, por um lado, o pensamento acerca de questões relevantes para se entender a condição judaica, ou o significado de judaísmo e da vida judaica. E, por outro lado, o pensamento filosófico que deve e responde à tradição da filosofia ocidental moderna e talvez à toda tradição filosófica ocidental e tem sido apropriado e modificado no período moderno". Isto é: a filosofia judaica nos ajuda a entender a vida judaica em si e responde às questões filosóficas como um todo.

Último Andar: Como você entende a influência do judaísmo para além da esfera religiosa? Como um judeu secular pode ser influenciado pela religião judaica?

Andréa Kogan: O judaísmo, na minha opinião e depois de tantas leituras e discussões sobre o assunto, não deve ser entendido como somente uma religião, mas também como identidade, cultura, nacionalidade e tantos outros aspectos que talvez seja impossível definir. Ou melhor - é impossível definir o judaísmo de uma só forma. O que seus filósofos e pensadores tentam é nos "dar pistas" de como viver a vida. Um judeu secular pode ser influenciado pelo judaísmo e não se dá conta - mas está sendo influenciado. Pode ser pela literatura de Amós Oz, por exemplo (um judeu ateu, por exemplo), mas também pela gastronomia, ou pela arte de Chagall, ou pela caminhada de A.J. Heschel com Martin Luther King.

Último Andar: No caso de um pensador fortemente influenciado pela lógica judaica, pode existir um abismo entre ele e um público cristão? Há alguma incapacidade de incompreensão? 
Andréa Kogan: Acredito que não. Acho que as aproximações entre o um pensador cristão e um pensador judaico existem e podem ser identificadas (obviamente cada um tendo sido influenciado polo seu pensamento - judaico ou cristão). O texto bíblico, quando discutido por estes dois "públicos", por exemplo, sempre é enriquecido. Como estudo judaísmo contemporâneo, não posso crer em abismos, estando em 2017. Creio em aproximações.

Último Andar: Para você, quais os principais dilemas do judaísmo na contemporaneidade? Eles diferem dos das outras religiões tradicionais?

Andréa Kogan: O dilema da contemporaneidade no judaísmo não é responder a pergunta: "você é judeu?", mas sim tentar responder a questão: "qual tipo de judeu você quer ser?". Assim é muito importante entender o "seu judaísmo" (seja ele ortodoxo, ortodoxomoderno, liberal, reformista, etc.) e viver bem com ele. O judeu vivendo no século XXI tem possibilidades de caminhos a serem percorridos pela frente, principalmente se vive em uma metrópole como São Paulo, por exemplo. Acredito que todas as religiões tradicionais devem estar refletindo sobre este aspecto no momento. Não é possível fechar os olhos para a existência de outros movimentos religiosos. Na década de 1980, o rabino Zalman SchachterShalomi (dos EUA) nos falou que precisávamos buscar um judaísmo além da versão pasteurizada que geralmente era encontrada, que este estava sendo "superverbalizado" e "subvivenciado". Acho que caminhamos um pouco nestes últimos anos, mas ainda há muito a se percorrer.

Último Andar: Suas pesquisas tratam da intersecção entre judaísmo e outros tipos de espiritualidade. Esse é um fenômeno particularmente contemporâneo? Você vê nisso a influência de movimentos como o Nova Era ou outras tendências recentes?

Andréa Kogan: É um fenômeno, sem dúvida, contemporâneo, mas precisa ser pensado em que contexto ele está inserido geograficamente. O judaísmo no Brasil tem características únicas, que não podem ser comparadas com nenhum "judaísmo" de nenhum outro país, nem da América Latina, muito menos dos EUA ou da Europa. A influência do espiritismo, da umbanda e do candomblé, no Brasil - na cultura brasileira -, também se mostra 
presente dentro do judaísmo brasileiro; de maneira semelhante, movimentos da Nova Era são refletidos no judaísmo aqui também - o movimento de Jewish Renewal, nos EUA, introduziu elementos de Nova Era no judaísmo daquele país. Acredito que, aqui no Brasil, foram as religiões afro que tiveram este papel. O brasileiro é naturalmente curioso em relação ao sobrenatural, não há dúvida nisso; o judeu no Brasil, obviamente, também tem esta curiosidade. $\mathrm{O}$ que acontece com os judeus inseridos numa cidade plural como São Paulo é receber a influência do que acontece nela. Claro que falo isso além da comunidade ortodoxa que vive de forma diferente: falo isso a respeito do judeu não-ortodoxo que está sendo influenciado diretamente pela "meditação" oferecida na academia onde frequenta, pelos "passes espíritas" na casas e nos centros espíritas, e pelas visitas aos terreiros de umbanda e candomblé que visita por curiosidade (ou frequenta).

\section{Último Andar: O quanto o judaísmo influenciou o seu próprio pensamento?}

Andréa Kogan: Vivi exclusivamente em ambiente judaico até os 17 anos. Creio que o judaísmo tenha se solidificado ali, e acredito que minha forma de pensar é bastante judaica. Ao voltar para os estudos judaicos no doutorado, percebi (e ainda percebo) que muito do que os filósofos e pensadores que estudo dizem é também minha forma de raciocinar e ver o mundo. Diz Luiz Felipe Pondé que o judaísmo é "viver na contingência": parece que isto resume muito o nosso modo de encarar a vida, principalmente pós-Holocausto. Amós Oz fala que, essencialmente, o judaísmo continua por causa do TEXTO. Creio que talvez isto resuma o pensamento que sigo: agir na contingência e continuar o estudo.

(por Isadora Sinay)

A revista Último Andar agradece Andréa Kogan, José Luiz Bueno,

Maria Cristina Mariante Guarnieri, Luiz Felipe Pondé, e toda a equipe do Núcleo de Estudos em Mística e Santidade

(NEMES) da PUC-SP pela colaboração. 